\title{
Analysis on the Production and Marketing Strategies of Oligopoly Companies Based on Cournot Model and Stackelberg Model
}

\author{
Xueyi Zhang * \\ Beijing Normal University Business School, Beijing, China, 100875
}

\begin{abstract}
By comparing Cournot model and Stackelberg model under complete information market and Cournot model unde $\mathrm{r}$ i ncomplete information $\mathrm{m}$ arket, this paper a nalyzes the i mpact that $\mathrm{m}$ anufacturer choose simultaneous or sequential games when determining the amount of output as well as the production and $\mathrm{m}$ arketing $\mathrm{s}$ trategy to maximize the profit of the manufacturers in the oligopoly $\mathrm{m}$ arket. A s pecific analysis is also conducted according to Gree air-conditioning manufacturer's data.
\end{abstract}

\section{INTRODUCTION}

In 2019 , b oth t he e xport s cale of the a ir-conditioning market an $\mathrm{d} t$ he $\mathrm{d}$ emand of domestic $\mathrm{m}$ arket $\mathrm{d}$ ecreased. The $\mathrm{m}$ arket $\mathrm{s}$ cale $\mathrm{w}$ as 191.2 bi llion $\mathrm{y}$ uan, $\mathrm{w}$ hich i s a year-on-year $g$ rowth of $-3.4 \%$ o ver 1 ast y ear, an $\mathrm{d} t$ he export a mount wa $\mathrm{s} 72.1$ bi llion yuan, the same a s last year. On N ovember 1 1, 2019, G ree E lectric launched a profit-sharing activity, starting the third obvious price war in the air-conditioning market [6].

In 2020, due to the impact of COVID-19, the number of c onsumers is further reduced, a nd a s a non-essential goods, $\mathrm{t}$ he $\mathrm{s}$ ellings cale of a ir $\mathrm{c}$ onditioners a re significantly suppressed. In addition, the rise of new sales forms s uch a s 1 ive-streaming a nd s ocial i nfluencer marketing a lso bring down the price of a ir-conditioning market. The air-conditioning market, therefore, falls into a $\mathrm{p}$ rice $\mathrm{w}$ ar a gain an $\mathrm{d} t$ he $\mathrm{l}$ eading $\mathrm{c}$ ompanies $\mathrm{s}$ eize $\mathrm{t}$ he opportunity t o gr ab $\mathrm{m}$ arket share by us ing their br and influence. Therefore, this paper will discuss how to gain greater $m$ arket $s$ hare an $d$ more $s$ ales $p$ rofits $i n t$ he air-conditioning $\mathrm{m}$ arket $\mathrm{w}$ hich ha $\mathrm{s}$ gr adually $\mathrm{f}$ ormed a duopoly market of Gree and Midea.

\section{LITERATURE REVIEW}

There are many documents that have conducted research on the competition strategy of ol igopoly market in order to find various factors that a ffect the competitiveness of those oligopoly enterprises.

Zhang Ya ming a nd $\mathrm{S} u$ Yanqi used $t$ he e xtended Hotelling m odel to a nalyze the $m$ arket e quilibrium and manufacturer profits when duopoly firms choose single or discriminatory $\mathrm{p}$ ricing $\mathrm{s}$ trategies, $\mathrm{r}$ espectively. $\mathrm{T}$ hey discussed $t$ he $i$ mpact of network e xternalities, $t$ he marginal cost and the willingness of consumers to pay for their $\mathrm{b}$ rand $\mathrm{l}$ oyalty $\mathrm{o} \mathrm{n} \mathrm{m}$ anufacturers' pricing $\mathrm{s}$ trategies [11]. Luo Qin (2008) studied the optimal decision-making of companies facing different profit margins based on the classic Cournot model. She established a discrete dynamic system $\mathrm{m}$ odel ba sed $\mathrm{o} \mathrm{n} t$ he ga me $\mathrm{t}$ heory of $\mathrm{r}$ esource oligarchs a nd found out the $\mathrm{Na}$ sh e quilibrium $\mathrm{p}$ oints of each manufacturer under cooperating and non-cooperating situation [4].

Mou Bojiao, Chen Jian, and Xiao Yongbo (2009) used the MNL model to c onduct r esearch and found that the equilibrium price of products in the oligopoly market goes up with the increase of costs, production's value and the cost of competitive products. In general, the equilibrium behavior of oligopoly firms is to provide product lines [5]. Liu Feng, Li Yaguang, and Wang Hongxing put forward by e stablishing a $\mathrm{f}$ our-oligarch price $\mathrm{g}$ ame $\mathrm{m}$ odel $\mathrm{t}$ hat oligopoly $\mathrm{m}$ anufacturers, wi th $\mathrm{t}$ he goal of $\mathrm{m}$ aximizing their o wn i nterests, $w$ ill $\mathrm{c}$ onstantly a djust their $\mathrm{p}$ roduct prices an $\mathrm{d} i$ gnore $t$ he e xternal ef fects of product price changes, $\mathrm{s} \mathrm{o}$ as $\mathrm{t}$ o $\mathrm{m}$ ake their ow $\mathrm{n}$ profits de cline eventually d ue $\mathrm{t}$ o market chaos. Therefore, product manufacturers s hould s ell a $\mathrm{t} l$ ower prices $\mathrm{t}$ o $\mathrm{m}$ aximize their ow $\mathrm{n}$ interests and a void changing prices frequently [3].

$\mathrm{Yu}$ Lin believes that oligopoly manufacturers can gain a certain oligopolistic advantage by continuously lowering the prices of their products, but at the same time, industry competition has intensified and the overall pr ofit of the industry has $\mathrm{d}$ eclined. $\mathrm{T}$ herefore, $\mathrm{m}$ anufacturers s hould focus on product differentiation in order to capture market share and avoid low-price competition [9].

Based on $\mathrm{t}$ he $\mathrm{C}$ ournot $\mathrm{m}$ odel a nd t he Stackelberg model, this article will discuss the production and marketing $\mathrm{s}$ trategies of $\mathrm{m}$ anufacturers i $\mathrm{n} \mathrm{t}$ he ol igopoly market and use Gree air-conditioning manufacturers as an example to conduct specific data analysis.

\footnotetext{
* Corresponding author: zzxueyizz@qq.com
} 


\section{MODEL CONSTRUCTION}

\subsection{Cournot Model Under Complete Information Market}

The C ournot m odel a ssumes that in a du opoly m arket, two $\mathrm{f}$ irms $\mathrm{t}$ ry $\mathrm{t}$ o $\mathrm{m}$ ake decisions a bout how $\mathrm{m}$ uch $\mathrm{t} \mathrm{o}$ produce at the same time. Each firm makes a r easonable prediction of $t$ he o utput of $t$ he ot her $\mathrm{f}$ irm i $\mathrm{n}$ o rder $\mathrm{t} o$ determine their own output that maximizes its profits. The model derives their respective reaction functions based on the predictions made by $t$ he two manufacturers, thereby obtaining $\mathrm{t}$ he $\mathrm{pr}$ edicted $\mathrm{e}$ quilibrium. I $\mathrm{n}$ traditional Cournot $m$ odel, $t$ wo firms a re a ssumed t o ha ve s ame marginal c osts. Howe ver, $\mathrm{i} \mathrm{n} \mathrm{r}$ eality, $\mathrm{t}$ he $\mathrm{m}$ arginal production costs of oligarchs are not completely the same. Therefore, the model in this article assumes that different firms have different marginal production costs.

It is assumed that the output of firm 1 and firm 2 a re determined a s q1 a nd q 2, respectively, a nd the $t$ otal supply of commodity in the market is $\mathrm{Q}=\mathrm{q} 1+\mathrm{q} 2$ (1). $\mathrm{P}$ represents the price of a unit commodity a nd a is the highest willingness to pay in this market. Therefore, the inverse demand function is $\mathrm{P}=\mathrm{a}-\mathrm{Q}=\mathrm{a}-(\mathrm{q} 1+\mathrm{q} 2)(2)$. Assuming that the fixed costs of the two firms are both 0 , the marginal cost of firm 1 is $\mathrm{c} 1$, and the marginal cost of firm 2 i s c 2, a nd the g oal of each firm is t o m aximize their own profit. Therefore, the profit function of firm $i$ is $\pi \mathrm{i}=\mathrm{qi} *(\mathrm{a}-\mathrm{q} 1-\mathrm{q} 2-\mathrm{ci}), \mathrm{i}=1,2$. (3)

By $f$ inding $t$ he $f$ irst-order $\mathrm{c}$ ondition o $\mathrm{ft}$ he profit functions of two firms, the reaction function of firm 1 is $\mathrm{q}_{1} *=\frac{\mathrm{a}-\mathrm{c}_{1}-\mathrm{q}_{2}}{2}$

$\mathrm{q}_{2} *=\frac{\mathrm{a}-\mathrm{c}_{2}-\mathrm{q}_{1}}{2}$

(4), $\mathrm{t}$ he $\mathrm{r}$ action function of $\mathrm{f}$ irm $2 \mathrm{i} \mathrm{s}$

(5). B y c ombining $t$ he $r$ eflection functions of the two firms, the equilibrium point in the model i s obt ained a $s \frac{a-2 c_{1}+c_{2}}{3}$ (6), $q_{2}{ }^{*}=\frac{a-2 c_{2}+c_{1}}{3}$ (7). $\mathrm{T}$ he $\mathrm{p}$ rice o $\mathrm{fc}$ ommodities $\mathrm{i} \mathrm{nt}$ he $\mathrm{m}$ arket $\mathrm{i} s$ $\mathrm{P}=\mathrm{a}-\left(\mathrm{q}_{1}+\mathrm{q}_{2}\right)=\frac{\mathrm{a}+\mathrm{c}_{1}+\mathrm{c}_{2}}{3}$

(8) and the profits of the $\mathrm{t}$ wo firms a re $\pi_{1}=\frac{\left(a-2 c_{1}+c_{2}\right)^{2}}{9}$ (9), $\pi_{2}=\frac{\left(a-2 c_{2}+c_{1}\right)^{2}}{9}(10)$, respectively.

\subsection{Cournot Model Under Incomplete Information Market}

The a ssumption of the Cournot model not only requires two $f$ irms $t$ o ha vea fixed $m$ arginal $c$ ost a nd homogenization of their products, b ut a lso r equires that the market information is completely symmetrical, that is, both firms know each other's marginal costs. However, in the real market, the marginal cost of s ome companies is not completely open $\mathrm{t}$ o competitors. $\mathrm{T}$ herefore, the Cournot m odel unde $r$ i ncomplete i nformation $m$ arket is also need to be introduced.

Assuming that the out put of firm 1 a nd firm 2 a re respectively determined as $\mathrm{q} 1$ and $\mathrm{q} 2$, the total supply in the $\mathrm{m}$ arket is $\mathrm{Q}=\mathrm{q} 1+\mathrm{q} 2$ (1), $\mathrm{P}$ is the price of a unit commodity, and a is the highest willingness to pay in the market, then the inverse demand function is $\mathrm{P}=\mathrm{a}-\mathrm{Q}=\mathrm{a}$ $(q 1+q 2)(2)$. Assuming $t$ hat $t$ he fixed $c$ osts of $t$ he $t$ wo firms are both 0 and the marginal cost of firm 1 is $\mathrm{c} 1$. The marginal cost of firm 2 is not completely certain to firm 1 . The probability that its marginal cost is $\mathrm{cH}$ is $\theta$ and the probability that it is c L is $1-\theta$. Therefore, the profit function of firm $i$ is $\pi i=q i *(a-q 1-q 2-c i), i=1,2$. (3)

By s eeking $t$ he $f$ irst-order $\mathrm{c}$ onditions $\mathrm{f}$ or $\mathrm{t}$ hose $\mathrm{t}$ wo profit f unctions, the reaction f unction of $\mathrm{f}$ irm $1 \mathrm{c}$ an $\mathrm{b} e$ conducted $\mathrm{w}$ hich $\mathrm{i}$

$q_{1}^{*}=\frac{\theta\left[a-q_{2} *\left(c_{H}\right)-c_{1}\right]+(1-\theta)\left[a-q_{2} *\left(c_{2}\right)-c_{1}\right]}{2}$

firm $\mathrm{b}$ is a high-cost $\mathrm{f}$ irm, then $\mathrm{i}$ ts $\mathrm{r}$ eaction $\mathrm{f}$ unction is $q_{2}^{*}\left(c_{H}\right)=\frac{a-q_{1}{ }^{*}-c_{H}}{2}$

low-cost $f \quad$ irm, $i$ ts $r$ $q_{2}{ }^{*}\left(c_{L}\right)=\frac{a-q_{1}{ }^{*}-c_{L}}{2}$ (13). $\mathrm{C}$ ombining $\mathrm{t}$ he $\mathrm{r}$ eaction functions of $t$ he $t$ wo $f$ irms we $c$ an ge $t \mathrm{t}$ he e quilibrium point $\mathrm{i} n \mathrm{t}$ he model which is $q_{1}^{*}=\frac{a-2 c_{1}+\theta c_{H}+(1-\theta) c_{L}}{3}$

$q_{2}^{*}\left(c_{H}\right)=\frac{a-2 c_{H}+c_{1}}{3}+\frac{1-\theta}{6}\left(c_{H}-c_{L}\right)$

$q_{2}{ }^{*}\left(c_{L}\right)=\frac{a-2 c_{L}+c_{1}}{3}+\frac{\theta}{6}\left(c_{H}-c_{L}\right)_{(16)}$.

Therefore, the profit of firm 1 is $\pi_{1}=\frac{\left[2 a-4 c_{1}+3 c_{H}-\theta c_{H}-(1-\theta) c_{l}\right] *\left[a-2 c_{1}+\theta c_{H}+(1-\theta) c_{l}\right]}{18}$ (17) and $t$ he p rofit o $\mathrm{f}$ firm 2 is $\pi_{2}=\frac{\left[2 a+2 c_{1}-3 c_{H}-\theta c_{H}-(1-\theta) c_{l}\right] *\left[2 a-4 c_{H}+2 c_{1}+(1-\theta)\left(c_{H}-c_{L}\right)\right]}{36}$

(18) when firm 2 is a high-cost firm, the profit firm 1 is $\pi_{1}=\frac{\left[2 a-4 c_{1}-3 \theta c_{H}+2 c_{l}+3 \theta c_{l}\right] *\left[a-2 c_{1}+\theta c_{H}+(1-\theta) c_{l}\right]}{18}$ 9) and $t$ he profit of $f$ irm $2 \mathrm{i} \quad \mathrm{s}$ $\pi_{2}=\frac{\left[2 a+2 c_{1}-3 \theta c_{H}-4 c_{l}+3 \theta c_{l}\right] *\left[2 a-4 c_{2}+2 c_{1}+\theta\left(c_{H}-c_{L}\right)\right]}{36}$ (20) when firm 2 is a low-cost firm.

\subsection{Stackelberg Model}

In actual production, in addition to the possibility that two oligarchs are required to determine production amount at the same time, there is also a situation in which two firms make de cisions on their own o utputs uccessively. Therefore, the Stackelberg model needs to be introduced in $t$ his $\mathrm{p}$ aper. In $\mathrm{t}$ his $\mathrm{m}$ odel, $\mathrm{i} \mathrm{t}$ i s a ssumed $\mathrm{t}$ hat a $\mathrm{f}$ irm determines $i$ ts amount of o utput a s a na tural leader and then a nother firm, a s a f ollower, a djusts i ts out put according to the leader's decision.

Assuming that firm 1 is the leader in the market and firm 2 i s the follower. The output of those two firms are $\mathrm{q} 1$ and $\mathrm{q} 2$ respectively. Then the total supply of goods in the $\mathrm{m}$ arket i s $\mathrm{Q}=\mathrm{q} 1+\mathrm{q} 2$.(1) $\mathrm{P}$ i s the $\mathrm{p}$ rice of a $\mathrm{u}$ nit commodity and a is consumer's highest willingness to pay in this market. Therefore, the inverse demand function of this product is $\mathrm{P}=\mathrm{a}-\mathrm{Q}=\mathrm{a}-(\mathrm{q} 1+\mathrm{q} 2)$.(2) Assuming that the marginal cost of firm 2 is $c 2$, then the profit of firm 2 is $\quad \pi_{2}=q_{2} *\left(P-c_{2}\right)=\left(a-q_{1}-q_{2}-c\right) q_{2}$ 
(21) and the $\mathrm{r}$ eaction f unction of $\mathrm{f}$ irm 2 , by s eeking a first-order $\mathrm{c}$ ondition on $\mathrm{i}$ ts pr ofit $\mathrm{f}$ unction, is obt ained as $q_{2}^{*}=\frac{a-c_{2}-q_{1}}{2}(22)$.

$\begin{array}{ccc}\text { Firm 1 } & \text { 's p } & \text { rofit i } \\ \pi_{1}\left(q_{1}, q_{2} *\right)=q_{1} *\left(P-c_{1}\right)=\frac{q_{1} *\left(a-2 c_{1}+c_{2}-q_{1}\right)}{2} & \text { (22). B y }\end{array}$ seeking a first-order condition on this profit function, firm 1 's optimal out put c an a lso be obt ained as $q_{1}^{*}=\frac{a-2 c_{1}+c_{2}}{2}$ function of firm 2 and its optimal output can be calculated, which is $q_{2}^{*}=\frac{a-2 c_{2}+c_{1}}{4}$ (24). The price of the commodity in the $m$ arket is $P=\frac{a+3 c_{1}}{4}(25)$. Therefore, the profit of firm $1 \quad i \quad s \quad \pi_{1}=\left(P-c_{1}\right) * q_{1}=\frac{\left(a-c_{1}\right) *\left(a-2 c_{1}+c_{2}\right)}{8}$ (26)and $t$ he pr ofit of $f$ irm 2 $\pi_{2}=\left(P-c_{2}\right) * q_{2}=\frac{\left(a+3 c_{1}-4 c_{2}\right) *\left(a-2 c_{1}+c_{2}\right)}{16}(27)$.

\section{A. Analysis of Gree Air Conditioning}

In recent years, the global economic climate has become worse and the economic growth of major economies such as the United States, the European Union and Japan has shown a significant slowdown. In 2019, the gross domestic pr oduct ( GDP) of C hina i ncreased by $6.1 \%$ year-on-year which is the lowest growth rate in 20 years. Domestic $\mathrm{m}$ arket $\mathrm{s}$ luggishness ha s be come a c ommon phenomenon in m any industries. Therefore, how to gi ve full $\mathrm{pl}$ ay $\mathrm{t}$ ot heir a dvantages a nd $\mathrm{s}$ uppress $\mathrm{t}$ heir competitors in a sluggish market is critical. The following will t ake $G$ ree ai $r$ co nditioner as an ex ample, $u$ sing the Cournot model for analysis.

In the air-conditioning market, according to the investigation, $\mathrm{t}$ he $\mathrm{c}$ ost of a $\mathrm{c}$ ommodity with a $\mathrm{m}$ arket quotation of about 2500 yuan is roughly as follows:

TABLE 1. PRODUCTION COST OF AIR CONDITIONER [8]

\begin{tabular}{|c|c|c|c|c|}
\hline Unit: yuan & Compressor & $\begin{array}{c}\text { Production of external parts } \\
\text { (evaporator, condenser) and } \\
\text { motor controller, etc. }\end{array}$ & $\begin{array}{c}\text { Manufacturing } \\
\text { costs }\end{array}$ & $\begin{array}{c}\text { Sales } \\
\text { costs }\end{array}$ \\
\hline Gree KFR-26GW/ (26556) FNDe-3 & 500 & 810 & 33.43 \\
\hline Other air conditioners & 515 & 831.75 & 357 & 1700.43 \\
\hline
\end{tabular}

Since the offline market share of Gree and Midea air conditioner in 2019 were $45.9 \%$ and $27.2 \%$ respectively and the sales volume of air conditioner far exceeded that of Haier air conditioner which ranked third, which means the a ir c onditioning market ha $\mathrm{s}$ gradually $\mathrm{f}$ ormed $\mathrm{a} n$ oligopoly in recent ye ars, this pa per a ssumes that there are only two firms, Gree and Midea, manufacturing and competing with each other in the air-conditioning market.

The commodities with the biggest demand are the air conditioners $w$ ith a price of 200 0-3000 y uan, a nd the second most demanded price ranges from 3000 to 4000 yuan. Only a bout $30 \%$ of c onsumers a re willing to pay more than 4000 yuan for an air conditioner. Therefore, it is a ssumed $t$ hat $t$ he hi ghest wi llingness t o pa y i $n t$ he air-conditioning market is 5000 yuan.

In $\mathrm{t}$ he $\mathrm{C}$ ournot $\mathrm{m}$ odel $\mathrm{u}$ nder $\mathrm{c}$ omplete $\mathrm{i}$ nformation market, c $1=1700.43$ yuan and c $2=1748.19$ y uan. In equilibrium, the production quantities of the two firms are $\mathrm{q}_{1}{ }^{*}=1116$ and $\mathrm{q}_{2}{ }^{*}=1068$ respectively. $\mathrm{U}$ nder that situation, the average price of air conditioners in the market i s 2816.21 yuan. $T$ herefore, $G$ ree $A$ ir Conditioning's profit was $1,244,957.57$ y uan and Midea Air Conditioning's profit was 1,140,659.60 yuan.

In $\mathrm{t}$ he $\mathrm{S}$ tackelberg $\mathrm{m}$ odel, $\mathrm{c} 1=1700.43 \mathrm{y}$ uan a nd $\mathrm{c} 2=1748.19$ yuan. I $\mathrm{ne}$ quilibrium, $\mathrm{t}$ he pr oduction quantities of the $\mathrm{t}$ wo $\mathrm{m}$ anufacturers ar e $\mathrm{q}_{1}{ }^{*}=1116$ and $\mathrm{q}_{2}{ }^{*}=1068$ respectively. $\mathrm{U}$ nder $\mathrm{t}$ hat $\mathrm{c}$ ondition, the av erage $\mathrm{p}$ rice of ai $\mathrm{r}$ co nditioners i $\mathrm{n} t$ he $\mathrm{m}$ arket is 2525.32 yuan. $T$ herefore, $t$ he pr ofit of $G$ ree a ir conditioning firm is $1,380,593.71$ yuan, and the profit of Midea air conditioning firm is $650,329.73$ yuan.
Since 2004, Gree has cooperated with Baosteel, which enabled $\mathrm{G}$ ree to o btain ai $\mathrm{r}$-conditioning $\mathrm{m}$ anufacturing materials at preferential prices. In 2005, Gree introduced the m ost a dvanced c ompressor production equipment in Zhuhai D oumen a nd s ince $t$ hen, it ha s i nvested in $t$ he construction of a $\mathrm{m}$ otor $\mathrm{m}$ atching $\mathrm{f}$ actory. $\mathrm{T}$ he improvement of $t$ hese ind ustrial $\mathrm{c}$ hains br ought a significant $r$ eduction of $t$ he pr oduction $c$ osts $f$ or Gree air-conditioning. Therefore, in this paper, it is a ssumed that the marginal production cost of Gree air-conditioning may decrease b y $30 \%$ o $\mathrm{nt}$ he original basis a nd $\mathrm{t}$ he probability is $50 \%$.

That i s, i n t he $\mathrm{C}$ ournot model u nder incomplete information market, Midea's marginal production cost is $c_{1}=1748.19$ yuan while Gr ee's m arginal pr oduction cost is $c_{H}=1700.43$ yuan, $c_{L}=1190.30$ yuan and $\theta=0.5$. The production quantities of the two firms in e quilibrium a re $\mathrm{q}_{1}^{*}=983, \mathrm{q}_{2}{ }^{*}\left(c_{H}\right)=1158$, $q_{2}{ }^{*}\left(c_{L}\right)=1498$. Therefore, when Gree is a high-cost firm, $G$ ree air-conditioning pr ofit is 1,341,629.93 yua $n$ and $\mathrm{M}$ idea air-conditioning profit is $1,091,642.98$ y uan whereas $w$ hen $G$ ree i s a l ow-cost fi rm, G ree air-conditioning pr ofit i s 1, 990,336.61 y uan a nd Mi dea air-conditioning profit is $1,128,528.89$ yuan.

From $\mathrm{t}$ he $\mathrm{r}$ esults a bove, $\mathrm{i} \mathrm{t} \mathrm{c}$ an be $\mathrm{s}$ een $\mathrm{t}$ hat $\mathrm{i} \mathrm{n} \mathrm{t}$ he complete i nformation $\mathrm{m}$ arket, $\mathrm{Gr}$ ee Ai $\mathrm{r} \mathrm{C}$ onditioning's profit as a leader in the Stackelberg model is higher than the pr ofit obt ained in $\mathrm{t}$ he $\mathrm{C}$ ournot m odel whi le i $\mathrm{n} t$ he Cournot model with incomplete information, the lower the marginal production cost of air conditioners is, the higher the out put i s, a nd t he l ower $t$ he e quilibrium pr ice of 
products in the market is, which means the profit of the firm is di rectly proportional to the out put and inversely proportional to the market equilibrium price.

\section{CONCLUSION}

When $\mathrm{t}$ he ol igopoly $\mathrm{m}$ arket is a c omplete i nformation market, firms should use their brand influence to become the leader of the market as much as possible and decide their own amount of output before other firms. When the oligopoly $\mathrm{m}$ arket i s a $\mathrm{n}$ i ncomplete i nformation $\mathrm{m}$ arket, firms s hould $r$ educe $t$ heir marginal production c osts a $s$ much as possible to expand their own scale of production and $\mathrm{s}$ eize $\mathrm{m}$ ore $\mathrm{m}$ arket $\mathrm{s}$ hare. A $\mathrm{t} t$ he $\mathrm{s}$ ame $\mathrm{t}$ ime, $\mathrm{t}$ hey should also control the rate of change in amount of output and price wi thin a $r$ easonable $r$ ange $t o$ avoid $l$ oss of profits caused by excessive decline in product prices.

\section{ACKNOWLEGEMENT}

Thanks to the professors and students who helped in the creation of $t$ his paper. I $t w$ as they $w$ ho en abled $m$ e $t o$ learn $\mathrm{m}$ ore $\mathrm{r}$ elevant $\mathrm{kn}$ owledge a nd c oncepts. $\mathrm{T}$ he completion of this paper was inseparable from their help.

\section{REFERENCES}

1. Hanif D. S herail, Al len L. S oyster, Frederic H. Murphy, S tackelberg-Nash-Cournot E quilibria: Characterizations a nd $\mathrm{C}$ omputations $[\mathrm{J}]$, Operations Research, 1983, 31(2): 253-276.

2. Koji Okuguchi, Cournot and Stackelberg Duopolies Revisited[J], Japanese Economic Review, 2002, 50(3): 363-367.

3. Liu F., Li Y. G., Wang H. X., Price Game Model of Four Oligopoly a nd I ts Complex $\mathrm{Ch}$ aracteristics under $\mathrm{N}$ onlinear $\mathrm{D}$ emand[J], J ournal of $\mathrm{S}$ ystem Engineering, 2016, 31(6): 719-728+839.

4. Luo Q., Research on Oligopoly Game of Renewable Natural Resources Based on Bounded Rationality[D], Jiangsu University, 2008.

5. Mou B. J., C heng J., X iao Y. B., R esearch on the Competitive Structure of $t$ he Product $L$ ine of Oligopoly Co mpanies_-Based o $\mathrm{n}$ the $\mathrm{D}$ iscrete Choice B ehavior of $\mathrm{C}$ ustomers[J], $\mathrm{J}$ ournal o $\mathrm{f}$ Tsinghua U niversity ( Philosophy and Social Sciences Edition), 2009, 24(1): 21-26.

6. National Household Appliance Industry Information Center, $\mathrm{C}$ hina $\mathrm{H}$ ome Appliance I ndustry A nnual Report (2019) [EB/OL], 2020, http://d.wanfangdata.com.cn/periodical/jydq202003 008 .

7. Simon $\mathrm{P}$. Anderson, Ma xim Engers $\mathrm{S}$ tackelberg versus $\mathrm{C}$ ournot oligopoly e quilibrium [ J], International J ournal of I ndustrial Organization, 1992, 10(1): 127-135.
8. Sun Y. R., price analysis of Gree air conditioner[D]. Zhengzhou: Zhengzhou University of Light Industry, 2016: 4-6.

9. Yu L., Game Analysis and Countermeasures of Price Competition in Ol igopoly Ma rket[J], Ma rket Modernization, 2006, (8): 44-45.

10. Zhang, Y. -B, L uo, X. -J, Z ou, X .-S, X ue, J .-Y, Generation market power and the influence o $\mathrm{f}$ bilateral trade o $\mathrm{n} \mathrm{it}[\mathrm{J}]$, P roceedings of $\mathrm{t}$ he $\mathrm{C}$ hinese Society of Electrical Engineering, 2004, 24: 18-23.

11. Zhang Y. M., Su Y. Q., Hotelling Pricing Model in Two-stage $\mathrm{D}$ uopoly $\mathrm{M}$ arket[J], $\mathrm{P}$ ractice and Understanding of Mathematics, 2017, 47(4): 25-34. 